\title{
Enhancement of some sex hormones concentrations by consumption of leaves extract of Viscum album (mistletoe) in rats
}

\author{
O.E. Ofem ${ }^{1}$, A.B. Antai' ${ }^{1}$ N.M. Essien², V.O. Oka, ${ }^{1}$ \\ ${ }^{1}$ Department of Physiology, College of Medical Sciences, University of Calabar, Nigeria, ${ }^{2}$ Department of Biochemistry, College of Medical \\ Sciences, University of Calabar, Nigeria.
}

\section{A B S T R A C T}

\begin{abstract}
Objective: This present study was conducted with the aim to investigate the effect of consumption of leaves extract of mistletoe on the concentration of some serum sex hormones (follicle stimulating hormone (FSH), luteinizing hormone (LH), testosterone and prolactin) in rats. Methods: Twenty-four (24) female albino Wistar rats (210-250 g final body weight) were randomly assigned into 4 groups of 6 rats each. Group 1 (control) took normal rat chow + drinking water. Group 2, extract treated-1 (ET-1), group 3, extract treated-2 (ET-2) and group 4, extract treated-3 (ET-3) in addition received $150 \mathrm{mg} / \mathrm{kg}, 300 \mathrm{mg} / \mathrm{kg}$ and $450 \mathrm{mg} / \mathrm{kg}$ respectively of $V$. album extract p.o once daily. The feeding regimens lasted for 4 weeks. Results: The serum concentrations of $\mathrm{FSH}, \mathrm{LH}$, testosterone and prolactin in control group were $0.95 \pm 0.09 \mu \mathrm{lU} / \mathrm{mL}, 1.21 \pm 0.10 \mu \mathrm{lU} / \mathrm{mL}, 6.78 \pm 0.19 \mathrm{ng} / \mathrm{mL}$ and $1.86 \pm 0.09 \mathrm{ng} / \mathrm{mL}$ respectively. FSH levels was significantly $(p<0.05)$ higher in ET-1 compared with control and ET-3. Serum concentrations of LH and testosterone were significantly $(p<0.05)$ higher in ET-1 and ET-2 compared with control; LH and testosterone concentrations were in turn significantly $(p<0.01)$ lower in ET-3 compared with ET-1 and ET-2. Prolactin decreased significantly $(p<0.05)$ in ET-1 and ET-2 compared with control. Conclusion: Moderate and controlled doses of mistletoe extract increases serum levels of $\mathrm{FSH}, \mathrm{LH}$ and testosterone but decreases prolactin concentrations, which could enhance reproductive functions in normal persons and those with loss-of reproductive function.
\end{abstract}

Key words: Viscum album, prolactin, testosterone, LH, FSH, rats

\section{INTRODUCTION}

The history of the use of herbs dates back to the time of the early man. ${ }^{1}$ Among herbal plants used in treatment of ailments is mistletoe (Viscum album), an idiosyncratic plant surrounded by age-old traditions of ancient cult and magic rites. ${ }^{2}$ It is an evergreen semi-parasitic plant that grows primarily on deciduous trees. ${ }^{3}$ It is found in Europe, North Africa, Asia and Nigeria. ${ }^{4}$ Phytochemical screening of Tapinanthus dodoneifolius (DC) Danser called "Kauchi" in Hausa a species of African mistletoe showed the presence of anthraquinones, saponins, tanins. ${ }^{5}$ European mistletoe has been widely researched, the primary chemical constituents has been found to vary according to the host plant but typically include glycoprotein, polypeptides (Viscotoxin), flavonoids, flavonol agylcones, lectins, triterpenes, saponins, caffeic acid, lignans, cholines derivatives related to acetylcholine, vitamin $\mathrm{C}$, histamine, resins, thionins, cardionolids and phenolic compounds. ${ }^{6-8}$

In ethnomedicine, the leaves of mistletoe are used to potentiate labour. The extract has been found to exhibit oxytocic activity ${ }^{4}$ on the uterine smooth muscle. ${ }^{9}$ From the earliest times mistletoe has been known to be one of the most magical, mysterious, and sacred plants of European folklore. It was considered to bestow life and fertility; its protects the body against poison; and also serves as an aphrodisiac. ${ }^{4,10,11} \mathrm{~A}$ decoction of the leaves of mistletoe is 
traditionally used in the treatment of a number of ailments, including management of fertility. ${ }^{12,13}$ It has been revealed that methods use by traditionalist in early diagnosis lack scientific basis. ${ }^{14}$

Fertility and reproductive health are regulated and maintained by the levels of serum sex hormones. With paucity in literature on the effect of mistletoe extract on serum sex hormones, it is therefore the aim of the present study to scientifically investigate into the effects of chronic consumption of mistletoe extract on some hormones of reproduction.

\section{MATERIALS AND METHODS}

\section{Experimental animals}

Twenty four female albino Wistar rats were obtained from the animal house of the Department of Physiology, University of Calabar, Nigeria. The rats weighed between 210-250 $\mathrm{g}$ at the time of sacrifice. They were weighed before commencement of the feeding experiment and thereafter were weighed daily. They were nursed under standard environmental condition. The research was conducted in accordance with the internationally accepted principles for laboratory animal use and care, as found in for example the European Community guidelines. ${ }^{15}$

\section{Experimental plant}

Four kilograms of fresh leaves of mistletoe (locally called ndoro-eyong) were purchased from a local market in Calabar-South Local Government of Cross River State, Nigeria, during the rainy season and were identified and authenticated as Viscum album by a botanist (Mr. Frank Adepoju) in the Department of Biological Sciences, University of Calabar, Nigeria.

\section{Preparation of plant extract}

Fresh leaves of $V$. album were first washed free of sand and debris. Wash water was blotted off and the leaves ground to paste. A quantity of the ground sample (50 g) was weighed and soxhlet extracted with $150 \mathrm{ml}$ distilled water at $100^{\circ} \mathrm{C}$ for $9 \mathrm{hr}$. In situations where larger ground samples were used, extraction was done under reflux with an appropriate volume of distilled water. The extract was slowly evaporated to dryness in vacuum at $40^{\circ} \mathrm{C}$ using a rotary evaporator. A total yield of $33.2 \%$ was obtained. Weighed (20 g in $10 \mathrm{ml}$ distilled water) samples of the extract were then used to prepare the stock solution $(500 \mathrm{mg} / \mathrm{ml})$ as previously described. ${ }^{16}$

\section{Feeding protocol}

The twenty four female albino Wistar rats were randomly assigned into four groups of 6 rats each. Group 1 served as control and was feds on normal rat chow + drinking water. Group 2, extract treated-1 (ET-1) received $150 \mathrm{mg}$ / $\mathrm{kg}$ of $V$. album extract p.o once daily. Group 3, extract treated-2 (ET-2) had $300 \mathrm{mg} / \mathrm{kg}$ of $V$. album extract p.o once daily while group 4, extract treated-3 (ET-3) received $450 \mathrm{mg} / \mathrm{kg}$ of $V$. album extract p.o once daily. They were all allowed free access to normal tap water as drinking water. The feeding regimens lasted for four weeks, the doses were derived from the $\mathrm{LD}_{50}$ value of $150 \mathrm{mg} / \mathrm{kg}$ body weight in mice obtained from our previous study.

\section{Collection of blood samples}

The animals were anaesthetized by inhalation of 3.5\% chloroform in a cotton swab and blood was collected via cardiac puncture into plain capped bottles and allowed to stand for 2 hours for effective clotting to occur. Serum was thereafter obtained and the samples were immediately used for the estimation of the different variables.

\section{Determination of serum levels of sex hormones}

Estimation of follicle stimulating hormone, luteinizing hormones, testosterone and prolactin concentrations were done using the Microwell FSH EIA enzyme immunoassay kit (Synton Bioresearch, Inc. USA). The absorbance of each sample was read at $450 \mathrm{~nm}$ against the substrate blank within 30 minutes.

\section{Statistical analysis}

Data are presented as mean \pm SEM. Data were analysed using a one way Analysis of Variance (ANOVA) then followed with post hoc test (Least Square Deviation). $\mathrm{P}$ value of less than 0.05 was declared as significant statistically.

\section{RESULTS}

Serum concentrations of follicle stimulating hormone was significantly $(p<0.05)$ higher in ET-1 compared with control and significantly lower in ET-3 compared with ET-1 $(p<0.001)$ and ET-2 $(p<0.01)$ respectively as shown in Figure 1.

Serum concentrations of luteinizing hormone was significantly $(\mathrm{p}<0.05)$ higher in ET-1 $(1.71 \pm 0.14 \mu \mathrm{IU} / \mathrm{mL})$ and ET-2 $(1.55 \pm 0.09 \mu / \mathrm{IU} / \mathrm{mL})$ compared with control $(1.21 \pm 0.10 \mu \mathrm{IU} / \mathrm{mL})$. It was significantly $(\mathrm{p}<0.01)$ lower in ET-3 $(0.90 \pm 0.09 \mu \mathrm{IU} / \mathrm{mL})$ compared with ET-1 and ET-2. (Figure 2).

Testosterone level in the control group was $6.78 \pm$ $0.19 \mathrm{ng} / \mathrm{mL}$. It was significantly higher in ET-1 $(7.50 \pm$ $0.18 \mathrm{ng} / \mathrm{mL} ; \mathrm{p}<0.05)$ and ET-2 (8.34 $\pm 0.17 \mathrm{ng} / \mathrm{mL}$; $\mathrm{p}<0.01)$ compared with control. ET-3 had significantly lower testosterone levels $(5.46 \pm 0.15 \mathrm{ng} / \mathrm{mL})$ than the control group ( $\mathrm{p}<0.05)$, ET-1 and ET-2 ( $<<0.001)$ (Figure 3). 
The mean concentrations of prolactin in the control, ET-1, ET-2 and ET-3 were $1.86 \pm 0.09 \mathrm{ng} / \mathrm{mL}, 1.57 \pm 0.16 \mathrm{ng} / \mathrm{mL}$, $1.00 \pm 0.13 \mathrm{ng} / \mathrm{mL}$ and $3.80 \pm 0.18 \mathrm{ng} / \mathrm{mL}$ respectively. Showing a significant $(\mathrm{p}<0.05)$ decrease in ET-1 and ET-2 and a significant $(\mathrm{p}<0.001)$ increase in ET-3 compared with control. Levels of prolactin in ET-3 was also significantly $(\mathrm{p}<0.001)$ lower compared with ET-1 and ET-2 (Figure 4).

\section{DISCUSSION}

The results of this investigation suggest that leaves extract of Viscum album contain potent agents with potentials to increase serum FSH, LH and testosterone concentrations and at the same time decrease serum prolactin concentrations. The increase in FSH, LH and testosterone levels would have

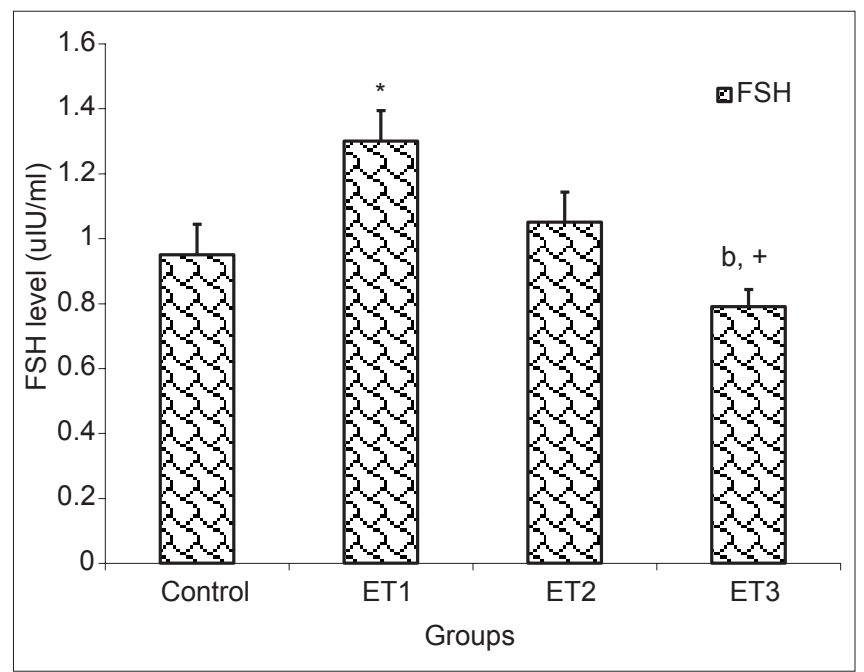

Figure 1: Effect of crude extract of Viscum album on follicle stimulating hormone $(F S H)$ level in rats. Values are mean + SEM. $n=5$. ${ }^{*} P<0.05$ vs control; $\mathrm{b}=\mathrm{P}<0.01$ vs $\mathrm{ET} 1 ;+=\mathrm{P}<0.001$ vs $\mathrm{ET} 2$

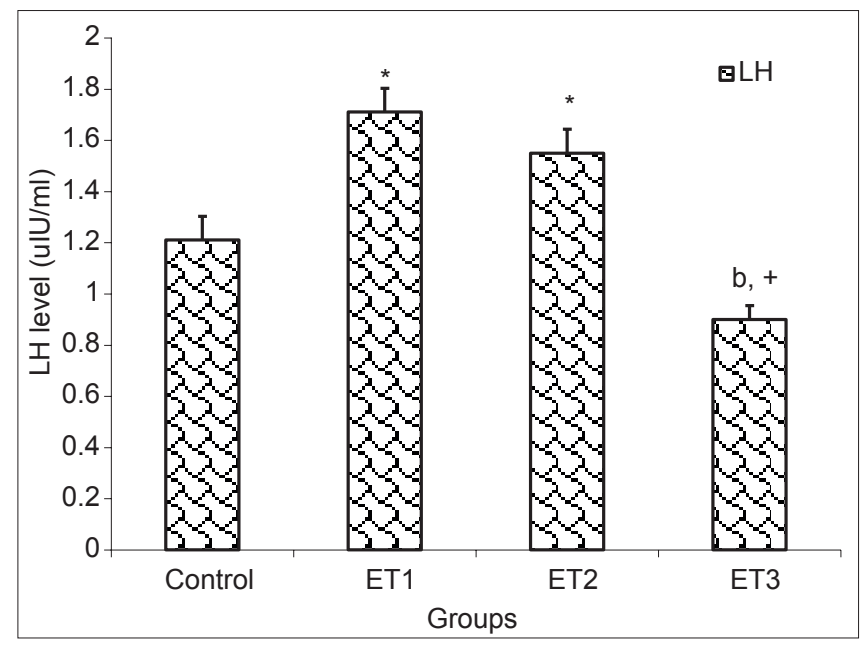

Figure 2: Effect of crude extract of Viscum album on luteinizing hormone (LH) levels in rats. Values are mean + SEM. $n=5 .{ }^{*} P<0.05$ vs control; $\mathrm{b}=\mathrm{P}<0.01$ vs $\mathrm{ET} 1 ;+=\mathrm{P}<0.01$ vs $\mathrm{ET} 2$ been due to some potent agents in the extract that stimulate the synthesis and subsequent release of these hormones in the anterior pituitary gland/ovary or probably promote cholesterol catabolism.

FSH and LH play essential roles in the control of mammalian reproductive function. In female mammals, FSH stimulates ovarian follicle growth and maturation, as well as $\mathrm{E}_{2}$ synthesis by granulosa cells, whereas LH stimulates androgen production by theca cells and ovulation of the dominant follicle(s). Women with loss-of function mutations in the FSHB or FSH receptor (FSHR) genes present clinically with primary or secondary amenorrhea and associated arrest in follicle development at the pre-antral stage. ${ }^{17,18}$ In this condition, moderate doses of mistletoe extract will be of immense benefits, since it will help ameliorate the

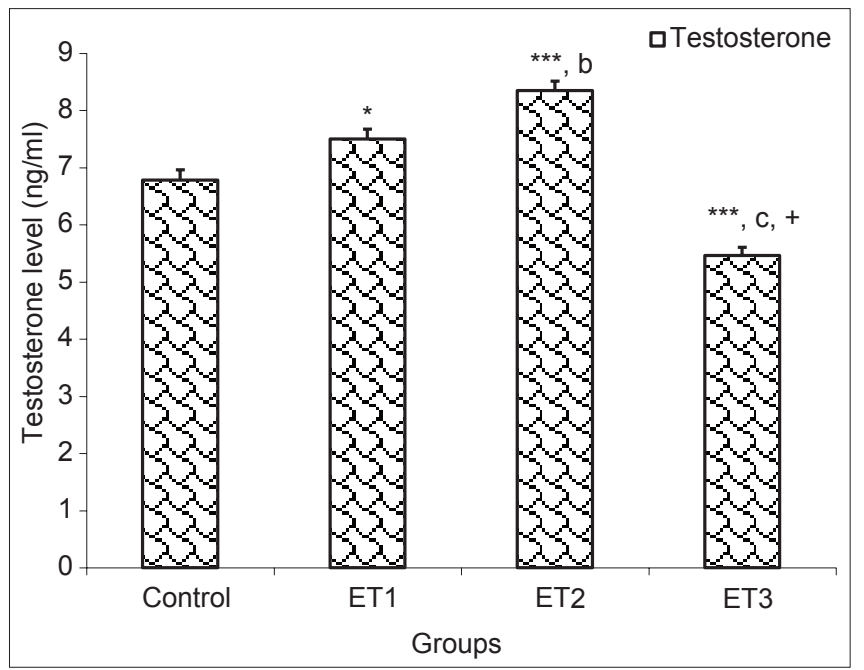

Figure 3: Effect of crude extract of Viscum album on testosterone level in rats. Values are mean $+\mathrm{SEM} . \mathrm{n}=5$. ${ }^{*} \mathrm{P}<0.05$, ${ }^{* * *} \mathrm{P}<0.001 \mathrm{vs}$ control; $\mathrm{b}=\mathrm{P}<0.01$ vs $\mathrm{ET}-1, \mathrm{c}=\mathrm{P}<0.001$ vs $\mathrm{ET}-1 ;+=\mathrm{P}<0.001$ vs $\mathrm{ET}-2$

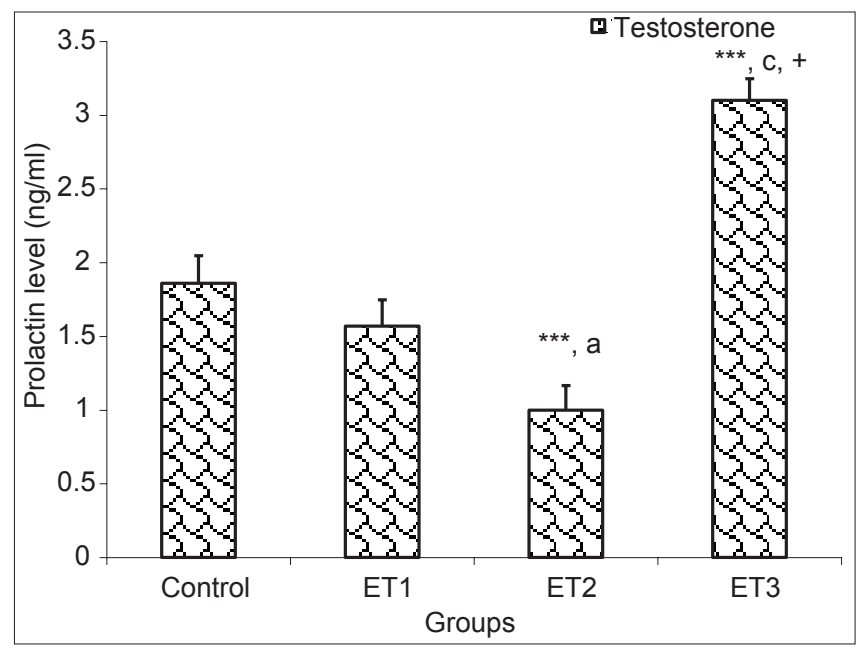

Figure 4: Effect of crude extract of Viscum album on prolactin levels in rats. Values are mean + SEM. $n=5 .{ }^{*} P<0.05,{ }^{* \star \star} P<0.001$ vs control; $\mathrm{a}=\mathrm{P}<0.05$ vs $\mathrm{ET}-1, \mathrm{c}=\mathrm{P}<0.001$ vs $\mathrm{ET}-1 ;+=\mathrm{P}<0.001$ vs $\mathrm{ET} 2$ 
malfunction. In males, LH stimulates androgen production by interstitial Leydig cells, although FSH targets Sertoli cells in the testes to regulate spermatogenesis.

An interesting aspect of this result is that shown by the group of rats fed with $450 \mathrm{mg} / \mathrm{kg}$ body weight, which caused significant decrease in concentrations of testosterone, FSH and LH but increased prolactin levels. The decrease in the levels of the hormones could be due to a negative feedback regulatory mechanism.

There is usually an inverse relationship between prolactin levels and the levels of testosterone. As prolactin levels increase, the levels of testosterone, estrogen and progesterone decrease, this has been reported by erudite scholars. ${ }^{19,20}$

The increase in prolactin concentrations observed in the high dose extract recipients could be due to blocking of dopamine by an opiate-like substance in the extract. Mistletoe is known for its anti-depressant function ${ }^{21}$ due to the presence of alkaloids in the extract. Anti-depressants are mostly opiate-like substances most of which inhibit dopamine activity, dopamine has been known to inhibit prolactin synthesis. Invariably, an increase in prolactin concentrations will lead to a decrease in testosterone concentration.

In conclusion, moderate and controlled doses of mistletoe increases serum levels of FHS, LH and testosterone but decreases prolactin concentrations.

\section{ACKNOWLEDGEMENT}

The authors of this article wish to acknowledge the assistance of Mr. Edetedet Umoh of the Department of Physiology, University of Calabar, Nigeria for helping to breed the rats used for this studies, he was also of immense benefit during the period of sacrifice and bile collection. Dr. Iya Ntui of Chemical Pathology, University of Calabar is worthy of mention, she took pain to analyze the biochemical composition from all the sample collected. Dr. Obem Okwari, the Chief Technology of Physiology Department, University of Calabar, Nigeria is also acknowledged for approving and making available some of the instruments used during the experiment.

\section{REFERENCES}

1. Kafaru E. Immense Help from Nature's Workshop (ed.), Elikaf Health Service Limited. London: Academic Press;1994.
2. Babara I and Theiss P. The family herbal healing A. Young Ed. Art Press, Rochester Vermont; 1992.

3. Hoffman D. The Holistic Herbal Medicine. New York: Longman Publishers; 1989.

3. Frohne D, Pfander HJ.(Eds.). Mistletoe. In: A colour Atlas of Poisonous Plants, (1 ${ }^{\text {st }}$ edition, pp. 155-156). London: Wolfe Publishers;1984.

5. Deeni $Y Y$ and Sadiq NM. Antimicrobial properties and phytochemiical constituents of the leaves of African mistletoe (Tapinanthus dodoneifolius (DC) Danser) an ethnomedicinal plant of Hausa land-North Nigeria. J Ethnopharm 2002;3:235240.

6. Edlund $U$, Hensel A, Frose $D$, Pfuller $U$ and Scheffler A. Polysaccharides from fresh viscum album L. berry extract and their Interaction with Viscum album agglutinin. I. Arzneimi Helforschung 2000; 50:645-651.

7. Wollenweber E, Wieland A and Haask A. Epicutical wax and flavonol aglycones of the European Mistletoe. Viscum album L. Zeitschrift Fur Naturforschung C-A. J Biosci 2000;55:311-317.

8. Lyu SY, Park SM, Cheng BY and Park WB. Comparative study of Korean (Viscum album var. coloratum) and European mistletoe (Viscum album L.). Arch Pharmacol Res 2000;23:592-598.

9. Le $\mathrm{O}$ and Zam N. Oxytocic properties of the aqueous extract of Globimetula braunii (loranthaceae). Pak J Pharm Sc. 2008;21(4):356-360.

10. Swain L. Ancient Legendary of Mistletoe. Gale Encyclopedia of Alternative Medicine. UK: Amason Gale Publishers;1995.

11. Jeff B. Legendry of Mistletoe. Journal of Herbal Research Foundation 2001;10: 1-6.

12. Fernandez T, Wagner ML, Varela BG, Ricco RA, Hajos SE and Gurni AA. Study of an Argentine Mistletoe, the hemiparasite. Ligaria cuneifolia (Loranthaceae). J Ethnopharm 1998;62:25-34.

13. Deliorman D, Calis T, Ergun F, Dogan BS, Buharalioghu CK and Kanzik K. Studies on the vascular effects of the fractions and phenolic compounds isolated from Viscum album. J Ethnopharm 2002;72:323-339.

14. Oyebola DDO. Definition, Classification and Description of Muscle In D. Center (Ed.) Clinical Medicine. Edinburgh: Churchill Livingstone 1980;7:280-282.

15. EEC., Council Directive 86/609/EEC of November 1986 on the approximation of laws, regulations and administrative provisions of the Member States regarding the protection of animals used for experimental and other scientific purposes. Off J Euro Comm 1986;L358:1-29.

16. Eno $\mathrm{AE}$, Owo OI, Itam EH and Konya RS. Contribution of lymphocytes in edema induced by venom from the wasp (Belonogaster fuscipennis). Pharmacol Biol 2001;39(4):247252.

17. Bernard DJ. Mechanisms of FSH synthesis. Fertil Steril 2010;93:2465-2485.

18. Sabharwal P, Glaser R, Lafuse W, Varma S, Liut, SQ, Arkins R, et.al. Prolactin synthesized and secreted by human peripheral blood. Proc Natl Aca. Sci USA 1992;89:7713-7716.

19. Tietz NW. Foundamental in Clinical Chemistry, $1^{\text {st }}$ Edition, W. B Saunders Company, Philadelphia;1994;1354-1373.

20. Guyton AC and Hall JE. (Eds). Textbook of Medical Physiology, (11 th edition). Philadelphia: W. B. Saunders Publishers;2004.

21. Carr BR and Blackwell RE. The everlasting mistletoe and the cardiovascular. Texas Institute Journal 1998;7:310-314. 